\title{
SYSTEMIC DISORDERS AFFECTING DENTAL PATHOLOGY
}

\author{
Knezevic R. Milan, ${ }^{1}$ Andjelic S. Gordana, ${ }^{2}$ Knezevic M. Milena ${ }^{3}$ \\ ${ }^{1}$ FEBOMFS, University Las Palmas, Spain \\ ${ }^{2}$ Institute for Medical Research, Military Medical Academy, Belgrade, Serbia \\ ${ }^{3}$ Medical School, University Las Palmas, Spain
}

Primljen/Received 20. 10. 2014. god.

\begin{abstract}
A retrospective overview of systemic disorders which might be associated with dental pathology is made. They are grouped as follows: (a) congenital dental developmental disorders, (b) chromosomal anomalies, (c) radiations, (d) immune disorders, (e) intoxications, (f) neurological alterations, (g) gastrointestinal diseases, (h) osteodystrophy and associated conditions, (i) skin diseases, (j) metabolic and endocrine disorders, (k) craniofacial malformation syndromes and other congenital general malformations. The associated dental pathology is described in each case.
\end{abstract}

Key words: Dental diseases, Symptoms, Systemic disease, Retrospective overview.

\section{INTRODUCTION}

Dental pathology may be divided into five etiological groups $/ 1 /$ infections (e.g., caries) $/ 2 /$, traumatisms /3/, disorders resulting from dental wear (e.g., attrition, erosion, and abrasion) $/ 4 /$, pathologic formations $/ 5 /$ and dental developmental disorders - the latter usually being associated to other extra oral clinical manifestations that may or may not form part of a common syndrome.

Many diseases and pathological conditions, involving practically all human apparatuses and systems, exhibit associated dental pathology or manifestations. The present study reviews those systemic disorders that may associate dental pathology, grouped as shown below. The grouping of such systemic diseases into categories is complicated; however, since group overlapping inevitably occurs. On reviewing the etiologies of dental disorders, no uniform classification criteria are to be found among the different authors who have addressed the subject. As an example, in the case of morphology - structural dental enamel defects, Neville et al. (1) propose an exhaustive classification comprising trauma to developing tissues, the ingestion of chemical
PrihvaćenAccepted 08. 12. 2014. god.

substances, chromosomal anomalies, infections, hereditary diseases, malnutrition, metabolic alterations and neurological disorders. In contrast, Wright (2) describes only three etiological groups: metabolic diseases, syndromic hereditary disorders and nonsyndromic hereditary disorders (e.g., amelo génesis imperfecta and other enamel developmental disorders). As commented above, the classification or grouping of the different diseases poses difficultness - particularly when referring to congenital disorders. In this context, it is accepted that in addition to the etiological factors associated to the dental anomalies described below, other underlying factors - probably genetic, related to tooth development and individual resistance to disease are also implicated (3).

\section{CONGENITAL ALTERATIONS OF TOOTH DEVELOPMENT}

In this first group of dental disorders associated to systemic pathology, mention should be made of taurodontism, characterized by the presence of large pulp chambers that can occupy the entire root. This dental condition is associated to the trichodentoosseous (TDO) syndrome, hypohidronic ectodermal dysplasia and Klinefelter's syndrome (4). All pacients with TDO syndrome present this malformation (5); in contrast, it is only observed in certain hypo maturate variants of amelogenesis imperfecta (6). This marked association between both entities suggests the existence of a genetic determining characteristic referred to as idiopathic dental fluorosis (4). On the other hand, $28.9 \%$ of paents with oligodontia suffer taurodontism of one or more, lower molars, with greatly diminished length of the mandibular cuspids and first molars in women (7). In turn, the hypoplastic form of amelogenesis imperfecta can manifest in combination with multiple unerupted teeth, hypercementosis and different root malformati- 
ons (8). In animals - specifically, in mice with transgenic cystic fibrosis (9) - anomalies have been observed in the form of soft whitish-blue enamel together with enamel of normal thickness and structure; ameloblasts that rapidly degenerate after the secretory phase, and enamel crystals of granular appearance and low molecular weight.

In the case of odontodysplasia associated to ectodermal dysplasia, clinical manifestations such as hypodontia and hypoplastic enamel appear (10).

Dentinogenesis imperfecta associated to osteogenesis imperfecta constitutes a structural anomaly affecting only the dentine. The teeth appear normal, though their development is abnormal (11); alterations in dentine formation occur in such cases (12). In experimental studies in rats, cyclosporine A has been shown to affect dentine formation, with alterations in the amount of secondary dentine appositioning and the generation of globular dental structures; the pulp is also affected in such situations (13).

\section{CHROMOSOMAL ANOMALIES}

Turner's syndrome involves morphological and volumetric dental alterations, with root abnormalities in lower molars and premolars, and reductions in size; the coronal portions of the incisors, canines and premolars are also affected (14), and the mesio-distal diameters are reduced (except in the upper canines) along with the vestibule lingual diameter of some teeth only (15). In Down syndrome the frequency of agenesis is 10 times greater than in the general population, with a higher incidence in males than in females. In order of descending frequency, agenesis affects the maxillary central incisors, the maxillary lateral incisors, the maxillary second premolars, and the mandibular second premolars (16). Microdontia is also observed. Another trisomy-involving chromosome 16 , is also associated to dental alterations. In this sense, decreases in the size of different dental organs have been documented in mice, together with the appearance of hypoplasias (17).

In one case of triple $\mathrm{X}$ syndrome the congenital absence of teeth was reported, with the presence of only one maxillary central incisor in both the deciduous and permanent dentition (18). Internals with a 45, XO karyotype, reductions in cuspid surface can be observed, along with decreases in volumenn -as reflectedby shortened mesiodistal and vestibulolingual diameters (19). Taurodontism has also been described (20). In Klinefelter's syndrome (males 47, XXY), important increments in enamel (but not of dentine) have been reported - in contrast to what is seen internals (21). As regards the gnostic condition $45, \mathrm{X} / 46, \mathrm{XX}$, $43 \%$ of the mandibular premolars have two roots - the proportion being approximately the same as internals with a 45, X karyotype (22).

\section{RADIATIONS}

Radiotherapy for head and neck cancer produces symptoms such as mucositis, oral dryness and taste alterations (23). A consequence of xerostomia is the increased risk of caries, which in these patients tend to be rapidly evolving, extensive and located in non-habitual zones (24). In children receiving radio-and chemotherapy, the number of dental anomalies has been found to increase (25).

\section{INTOXICATIONS}

Dental pathology associated to drug ingestion is diverse (26). As regards the production of caries, three groups of drugs can be cited: (a) those containing saccharose as excipient; (b) drugs that depress salivation and there-fore reduce the action of salivary caryoprophylactic agents in general (ie., buffer systems, dilution effect, etc.) - including tricyclic antidepressants, antipsychotic drugs, antihistamines, medication for arthritis, analgesics, diuretics, muscle relaxants, antiarrhythmic drugs, anticonvulsive agents, antidiarrhea formulations, antihypertensive drugs, medication for Parkinson's disease, antispasmodic drugs, anorexigenic agents; and (c) lithium-containing drugs. Drug intoxications can also cause dental discoloration, e.g., topical tin fluoride and systemically administered flours, chlorhexidine (though in this concrete case the dental plaque rather than the actual dental structure is stained), tetracyclines and ciprofloxacin. Regarding morpho-structural alterations of teeth, phenytoin should be mentioned, as it produces shortening, resorption and increased cement deposisitioning turn; local anesthetics are cytotoxic for tooth enamel and can interfere with amelogenesis when introduced under pressure into deciduous tooth ligaments. Additionaly, they may cause enamel hypoplasias in permanent dentition. Lastly, doxapram has been reported to induce the pre-mature appearance of dental germs (27).

\section{GASTROINTESTINAL DISEASES}

One of the most frequent dental alterations is erosion associated to gastrointestinal disorders. An example of this is provided by voluntary regurgitation (28), where the acid gastric contents attack the dental surface, causing progressive dental erosion (wear). In such situations the patient suffers marked dental hard tissue loss in the anterior group, and even in the palatine (lingual) surfaces of the premolars - to the point of exposing the pulp chambers. These alterations may in turn 
be associated to dental discoloration. Similar effects are observed in patients with gastro esophageal reflux, where continuous exposure to low $\mathrm{pH}$ values leads to irreversible loss of dental substance once the salivary buffering capacity has been overcome $(29,30)$.

Patients with celiac disease have been found to suffer an increased incidence of amelogenesis imperfecta and other enamel developmental defects (31). In turn, Gardner's syndrome involves dental anomalies associated to maxillary osteomas.

\section{OSTEODYSTROPHY AND ASSOCIATED CONDITIONS}

In two siblings with dwarfism, severe microcephaly has been observed in association with generalizad microdontia (32). The appearance of dental dyschromia (gray-yellowish teeth) has also been described, probably as a residue of connective tissue alterations — in one case associated to osteopenia, fetal hydrops and communicating hydrocephalus (33). In three patients in whom retarded growth was associated to hypotonus and hypotrophy, microdontia with extensive diastases were recorded (34).

In the Hallermann-Streiff syndrome, generalized (though sometimes occasional) microdontia can be observed (35), as well as hypodontia, persistent deciduous dentition, enamel developmental defects, late dental development, mandibular hypoplasia, and caries (36). A typical feature of this syndrome is the proximity of the lower molar root apexes to the inferior mandibular mar-gin (37). Ehlers-Danlos mucopolysaccharidosis (type VII syndrome) involves the appearance of microdontia with yellowish discoloration ofthe teeth, and caries. Radiologicaly, marked dentinal opacity is observed (38). In turn, Ehlers-Danlos syndrome type I may present imperfect dentinogenesis (particularly of the mandibular incisors), alterations in root size, and occasionally also root hypoplasia or aplasia. Histologically, giant root canals are observed, with pulp calcifications and vascular inclusions (39). In the Winchester syndrome - another example of mucopolysaccharidosis - a clinical case has been reported involving the presence of supernumerary teeth together with unerupted teeth, irregularly spaced teeth and caries (40).

This extensive group of syndromes also comprises the following disorders: infiltrating congenital li- pomatosis, with unilateral coronal enlargement or ma-crodontia, anomalous root formation and chronic periodontitis (41); tumor al calcinosis, where in addition to microdontia and dental structural wear the dental alterations may also involve the root and dental pulp, with the formation of short and bulbous roots, taurodontism ofthe first molars, pulp calcifications and partial pulp obliteration (42); and pyknodysostosis, where in one documen-ted case sharpened teeth with narrow pulp chambers were observed, together with enamel and root developmental alterations, malocclusion and caries (8).

Dwarfism associated to Grebe chondrodysplasia involves permanent dentition hypodontia along with diminished dental volume; additional findings include delayed formation and eruption of retained deciduous teeth. The jaws are hypoplastic (42). The Russell-Silver syndrome is in turn quite similar as regards the dental manifestations, with hypodontia, microdontia, delayed eruption, an arched palate, and crowding (39, 41 ); in another case reported in the literature, additional findings comprised the presence of double teeth in the deciduous dentition $(40,41)$. This form of dwarfism also manifests in the facial region, with an inverted orientation of the labial commissures.

\section{CONCLUSION}

The oral cavity is an important, very specific anatomical location with a significant role in many critical physiologic processes, such as digestion, respiration, and speech. It is also unique for the presence of exposed hard tissue surrounded by mucosa. Diseases of the tissues of the oral cavity can be categorized in the various groups: viral, hormonal, fungal, bacterial, dermatological, pharmaceutical, systemic disease, non-cancerous growths, psychiatric disorders, cancer and genetics. The primary and most important factor contributing to oral disease is tobacco use. However, other factors such as: alcohol beverage use, bad oral hygiene, diabetes and other medical conditions affecting the immune system, medications, stress and genetics can all play a role. The mouth is frequently involved in conditions that affect the skin or other multiorgan diseases. In many instances, oral involvement precedes the appearance of other symptoms or lesions at other locations. 


\title{
Sažetak
}

\section{SISTEMSKE BOLESTI KOJE UTIČU NA ZUBNU PATOLOGIJU}

\author{
Knezevic R. Milan, ${ }^{1}$ Andjelic S. Gordana, ${ }^{2}$ Knezevic M. Milena ${ }^{3}$ \\ ${ }^{1}$ FEBOMFS, University Las Palmas, Spain \\ 2 Institute for Medical Research, Military Medical Academy, Belgrade, Serbia \\ ${ }^{3}$ Medical School, University Las Palmas, Spain
}

Prikazan je retrospektivni pregled sistemskih poremećaja koji mogu biti povezani sa zubnom patologijom. Oni su grupisani na sledeći način: (a) kongenitalni dentalni razvojni poremećaji, (b) anomalije hromozoma, (c) zračenja, (d) poremećaji imunskog sistema, (e) trovanja, (f) neurološki poremećaji, (g) gastrointestinalne bolesti, (h) osteodistrofija i slični poremećaji, (i)

\section{REFERENCES}

1. U.S. Department of Health and Human Services. Oral health in America: a report of the Surgeon General. Rockville, Md.: U.S. Department of Health and Human Services, National Institute of Dental and Craniofacial Research, National Institutes of Health; 2000.

2. Janket SJ, Baird AE, Chuang SK, Jones JA. Meta-analysis of periodontal disease and risk of coronary heart disease and stroke. Oral Surg Oral Med Oral Pathol Oral Radiol Endod. 2003; 95(5): 559-69.

3. Xiong X, Buekens P, Fraser WD, Beck J, Offenbacher S. Periodontal disease and adverse pregnancy outcomes: a systematic review. BJOG. 2006; 113(2): 135-43.

4. Demmer RT, Jacobs DR Jr, Desvarieux M. Periodontal disease and incident type 2 diabetes: results from the First National Health and Nutrition Examination Survey and its epidemiologic follow-up study. Diabetes Care. 2008; 31(7): 1373-9.

5. Moazzez AH, Alvi A. Head and neck manifestations of AIDS in adults. Am Fam Physician. 1998; 57(8): 1813-22.

6. Gonsalves WC, Chi AC, Neville BW. Common oral lesions: Part I. Superficial mucosal lesions. Am Fam Physician. 2007; 75(4): 501-7.

7. Neville BW, Damm DD, Allen CM, Bouquot JE. Pernicious anemia. In: Oral and Maxillofacial Pathology. 3rd ed. St. Louis, Mo.: Saunders Elsevier; 2009: 829-31.

8. Schirdt M. Oral manifestations of lupus erythematosus. Int J Oral Surg. 1984; 13(2): 101-47.

9. Nico MM, Vilela MA, Rivitti EA, Lourenço SV. Oral lesions in lupus erythematosus: correlation with cutaneous lesions. Eur J Dermatol. 2008; 18(4): 376-81.

10. Callen JP. Oral manifestations of collagen vascular disease. Semin Cutan Med Surg. 1997; 16(4): 323-7.

11. Jessop S, Whitelaw DA, Delamere FM. Drugs for discoid lupus erythematosus. Cochrane Database Syst Rev. 2009; (4): CD002954.

12. Sirois DA, Fatahzadeh M, Roth R, Ettlin D. Diagnostic patterns and delays in pemphigus vulgaris: experience with 99 patients. Arch Dermatol. 2000; 136(12): 1569-70.

13. Hyams JS. Extraintestinal manifestations of inflammatory bowel disease in children. J Pediatr Gastroenterol Nutr. 1994; 19(1): 7-21. kožna oboljenja, (j) metabolički poremećaji i endokrine bolesti, (k) kraniofacijalni sindromi i udružene kongenitalne malformacije. Za svaki slučaj je ponaosob data udružena dentalna patologija.

Ključne reči: bolesti zuba, simptomi, sistemske bolesti, retrospektivni pregled.

14. Pittock S, Drumm B, Fleming P, et al. The oral cavity in Crohn's disease. J Pediatr. 2001; 138(5): 767-71.

15. Coenen C, Börsch G, Müller KM, Fabry H. Oral inflammatory changes as an initial manifestation of Crohn's disease antedating abdominal diagnosis. Report of a case. Dis Colon Rectum. 1988; 31(7): 548-52.

16. Talbot T, Jewell L, Schloss E, Yakimets W, Thomson AB. Cheilitis antedating Crohn's disease: case report and literature update of oral lesions. J Clin Gastroenterol. 1984; 6(4): 349-54.

17. Plauth M, Jenss H, Meyle J. Oral manifestations of Crohn's disease. An analysis of 79 cases. J Clin Gastroenterol. 1991; 13(1): 29-37.

18. Field EA, Tyldesley WR. Oral Crohn's disease revisited - a 10-yearreview. Br J Oral Maxillofac Surg. 1989; 27(2):1 14-23.

19. Strakosch CR, Gordon RD. Early diagnosis of Addison's disease; pigmentation as sole symptom. Aust N Z J Med. 1978; 8(2): 189-90.

20. Mealey BL. Periodontal disease and diabetes. A two-way street [published correction appears in J Am Dent Assoc. 2008; 139(3) :252]. J Am Dent Assoc. 2006; 137(suppl): 26S-31S.

21. Moore PA, Weyant RJ, Mongelluzzo MB, et al. Type 1 diabetes mellitus and oral health: assessment of periodontal disease. J Periodontol. 1999; 70(4): 409-17.

22. Taylor GW, Burt BA, Becker MP, et al. Non-insulin dependent diabetes mellitus and alveolar bone loss progression over 2 years. J Periodontol. 1998; 69(1): 76-83.

23. Teeuw WJ, Gerdes VE, Loos BG. Effect of periodontal treatment on glycemic control of diabetic patients: a systematic review and metaanalysis. Diabetes Care. 2010; 33(2): 421-7.

24. Janket SJ, Wightman A, Baird AE, Van Dyke TE, Jones JA. Does periodontal treatment improve glycemic control in diabetic patients? A metaanalysis of intervention studies. J Dent Res. 2005; 84(12): 1154-9.

25. Stewart JE, Wager KA, Friedlander AH, Zadeh HH. The effect of periodontal treatment on glycemic control in patients with type 2 diabetes mellitus. J Clin Periodontol. 2001; 28(4): 306-10.

26. Grossi SG. Treatment of periodontal disease and control of diabetes: an assessment of the evidence and need for future research. Ann Periodontol. 2001; 6(1): 138-45. 
27. Rodrigues DC, Taba MJ, Novaes AB, Souza SL, Grisi MF. Effect of nonsurgical periodontal therapy on glycemic control in patients with type 2 diabetes mellitus [published correction appears in J Periodontol. 2004; 75(5): 780]. J Periodontol. 2003; 74(9): 1361-7.

28. Darré L, Vergnes JN, Gourdy P, Sixou M. Efficacy of periodontal treatment on glycaemic control in diabetic patients: A meta-analysis of interventional studies. Diabetes Metab. 2008; 34(5): 497-506.

29. Thorstensson H, Kuylenstierna J, Hugoson A. Medical status and complications in relation to periodontal disease experience in insulindependent diabetics. J Clin Periodontol. 1996; 23(3 pt 1): 194-202.

30. Shultis WA, Weil EJ, Looker HC, et al. Effect of periodontitis on overt nephropathy and end-stage renal disease in type 2 diabetes. Diabetes Care. 2007; 30(2): 306-11.

31. IDF Clinical Guidelines Task Force. IDF guideline on oral health for people with diabetes. Brussels, Belgium: International Diabetes Federation; 2009.

32. Dreizen S, McCredie KB, Keating MJ, Luna MA. Malignant gingival and skin "infiltrates" in adult leukemia. Oral Surg Oral Med Oral Pathol. 1983; 55(6): 572-9.

33. Levy-Polack MP, Sebelli P, Polack NL. Incidence of oral complications and application of a preventive protocol in children with acute leukemia. Spec Care Dentist. 1998; 18(5): 189-93.

34. Glenny AM, Fernandez Mauleffinch LM, Pavitt S, Walsh T. Interventions for the prevention and treatment of herpes simplex virus in patients being treated for cancer. Cochrane Database Syst Rev. 2009; (1): CD006706.

\section{Correspondence to /Autor za korespondenciju}

Prof. dr Knezevic R. Milan

FEBOMFS, University Las Palmas, Spain

Emailmakmilk1@gmail.com
35. Worthington HV, Clarkson JE, Eden OB. Interventions for preventing oral mucositis for patients with cancer receiving treatment. Cochrane Database Syst Rev. 2007; (4): CD000978.

36. Pereira Pinto L, de Souza LB, Gordón-NúZez MA, et al. Prevention of oral lesions in children with acute lymphoblastic leukemia. Int J Pediatr Otorhinolaryngol. 2006; 70 (11): 1847-51.

37. Cheng KK, Chang AM, Yuen MP. Prevention of oral mucositis in paediatric patients treated with chemotherapy; a randomised crossover trial comparing two protocols of oral care. Eur J Cancer. 2004; 40(8): 1208-16.

38. Stokman MA, Spijkervet FK, Boezen HM, Schouten JP, Roodenburg JL, de Vries EG. Preventive intervention possibilities in radiotherapy- and chemotherapy-induced oral mucositis: results of meta-analyses. J Dent Res. 2006; 85(8): 690-700.

39. Valena V, Young WG. Dental erosion patterns from intrinsic acid regurgitation and vomiting. Aust Dent J. 2002; 47(2): 106-15.

40. Dynesen AW, Bardow A, Petersson B, Nielsen LR, Nauntofte B. Salivary changes and dental erosion in bulimia nervosa. Oral Surg Oral Med Oral Pathol Oral Radiol Endod. 2008; 106(5): 696-707.

41. Riad M, Barton JR, Wilson JA, Freeman CP, Maran AG. Parotid salivary secretory pattern in bulimia nervosa. Acta Otolaryngol. 1991; 111(2): 392-5.

42. Mehler PS, Wallace JA. Sialadenosis in bulimia. A new treatment. Arch Otolaryngol Head Neck Surg. 1993; 119(7): 787-8. 